\title{
PENYEBARAN DAN DETEKSI MOLEKULER VIRUS GEMINI PENYEBAB PENYAKIT KUNING PADA TANAMAN CABAI DI SUMATERA
}

\author{
Sudiono $^{1}$, Nur Yasin ${ }^{1}$, Sri Hendrastuti Hidayat ${ }^{2}$ dan Purnama Hidayat $^{2}$
}

\begin{abstract}
The distribution and molecular detection of geminivirus pathogen of chilli yellowing disease in Sumatera Island. The objective of this research was to investigate the spread and to detect geminivirus in Sumatra Island. The method is survey infected of plants in Province of Lampung, South Sumatra, Bengkulu, Jambi, West Sumatra, and North Sumatra was used to detection of geminivirus from collected chilli plants by PCR (polymerase reaction chain) technique. The result showed that based on typical symptoms and molecular detection of collected sample from Lampung, South Sumatera, and North Sumatera were infected by geminivirus. The type symptoms were turning yellowing, curling, and stunting. Occurrence of disease accidents were for Province of Lampung 0 - 100\%, South Sumatra 20 - 60\%, Bengkulu 0 - 40\%, Jambi 0 - 5\%, West Sumatra $0-5 \%$ and North Sumatra $0-80 \%$, while sample Province of Jambi and of West Sumtera were not infected by geminivirus based on symptoms and molecular detection.
\end{abstract}

Key words : Gemini virus, PCR

\section{PENDAHULUAN}

Penyakit yang disebabkan oleh virus gemini disebut juga dengan penyakit kuning, penyakit bulai, dan penyakit kerdil. Virus gemini merupakan golongan virus tumbuhan yang unik karena memiliki morfologi yang berbeda dengan golongan virus tumbuhan lainnya. Partikel virus gemini berbentuk isometri dan selalu berpasangan (geminate). Virus gemini memiliki genom berupa asam nukleat deoksiribonukleat (DNA) dalam bentuk utas tunggal [single stranded (ssDNA)] (Harrison, 1985; Lazarowitz, 1987).

Virus gemini dibedakan menjadi tiga kelompok berdasarkan tanaman inang, serangga vektor, dan struktur genomnya. Kelompok I adalah virus gemini yang menginfeksi tanaman monokotil, ditularkan oleh serangga vektor wereng daun, dan memiliki struktur genom monopartit. Kelompok II virus gemini yang menginfeksi tanaman dikotil, ditularkan oleh serangga vektor wereng daun, dan struktur genomnya monopartit. Kelompok III adalah geminiviurs yang menginfeksi tanaman dikotil, ditularkan oleh serangga vektor kutukebul, dan struktur genomnya bipartit (Matthews, 1991). Virus gemini dalam kelompok III memiliki daerah penyebaran yang sangat luas terutama di daerah tropika dan subtropika dimana kutukebul (Bemisia tabaci Genn.) dapat berkembang dengan baik.

Di Meksiko, Venezuela, Brazil, Amerika Serikat

\footnotetext{
${ }^{1}$ Dosen Jurusan Proteksi Tanaman Fakultas Pertanian Unila

2 Dosen Departemen Proteksi Tanaman Fakultas Pertanian IPB
}

(Florida), dan di beberapa negara di Amerika Tengah serta Karibia serangan virus gemini mengakibatkan hancurnya industri tomat (Polston \& Anderson, 1997). Serangan tomato yellow leaf curl virus gemini di Israel dan virus gemini isolat cabai di Texas menyebabkan kehilangan hasil mencapai 100\% (Pico et al., 1996; Stenger et al., 1990). Di Indonesia virus gemini pertama kali diketahui menyerang tanaman tembakau di Bojonegoro, Jawa Timur yang mengakibatkan kerusakan sebesar 30\% (Poerbokoesoemo, 1984 dalam Trisusilowati, 1990). Infeksi virus gemini juga telah terdeteksi pada tanaman cabai di daerah Jawa Barat, DI Yogyakarta dan Kalimantan Selatan (Rusli et al., 1999; Sulandari et al., 2001; Aidawati et al., 2001), dan pada tanaman tomat di Jawa Barat dan Kalimantan Selatan (Sudiono et al., 2001). Lebih lanjut melalui analisis pola pemotongan enzim restriksi dari fragmen DNA hasil amplifikasi dengan teknik polymerase chain reaction (PCR-RFLP), Hidayat et al. (1999) telah berhasil membedakan virus gemini asal cabai dari beberapa daerah di Bogor, Jawa Barat (Segunung, Cugenang dan Baranangsiang).

Serangan virus gemini pada pertanaman cabai di daerah Segunung, Bogor mencapai 100\% yang mengakibatkan kerugian yang sangat besar bagi petani cabai. Tingginya serangan ini diduga berkaitan dengan populasi kutukebul (Rusli et al., 1999). Mehta et al. (1994) dan Nooraidawati et al., (2002) melaporkan bahwa persentase tanaman yang terserang akan meningkat dengan meningkatnya jumlah kutukebul yang viruliferous. 
Penelitian ini bertujuan untuk mengetahui penyebaran virus gemini di pulau Sumatera dan mendeteksi virus tersebut pada tanaman cabai yang terdapat di sentra-sentra pertanaman cabai di Sumatera menggunakan teknik polymerase chain reaction (PCR).

\section{METODE PENELITIAN}

Waktu dan Tempat Penelitian. Penelitian terdiri atas tiga kegiatan, yaitu (1) pengamatan lapangan berupa gejala dan kejadian penyakit, (3) perbanyakan inokulum; dan (3) deteksi virus tanaman sampel dengan teknik PCR. Perbanyakkan dan pemeliharaan isolat virus dan kutukebul dilaksanakan di Laboratorium Bakteri dan Virologi Tumbuhan dan Rumah Kaca Jurusan Hama dan Penyakit Tumbuhan Fakultas Pertanian Universitas Lampung. Deteksi isolat-isolat virus dan dilaksanakan di Laboratorium Virologi Tumbuhan Jurusan Hama dan Penyakit Tumbuhan Fakultas Pertanian Institut Pertanian Bogor. Penelitian dilaksanakan dari bulan Mei sampai dengan Desember 2004.

Pengamatan Gejala dan Kejadian Penyakit di Lapangan. Tanaman cabai yang menunjukkan gejala seperti terinfeksi virus gemini dikumpulkan dari lokasi lahan petani maupun kebun percobaan milik instansi pemerintah di beberapa tempat yaitu Lampung, Sumatera Selatan, Bengkulu, Jambi, Sumatera Barat dan Sumatera Utara. Selanjutnya dilakukan deteksi dengan teknik PCR. Sampel tanaman yang menunjukkan hasil yang positif dengan PCR dipelihara di rumah kaca dan perbanyakan isolat virus dilakukan pada tanaman cabai. Kejadian penyakit dilapangan dilakukan dengan rumus sebagai berikut:

$$
\begin{aligned}
& \mathrm{K}=\mathrm{n} / \mathrm{N} \times 100 \% \\
& \text { Keterangan: } \\
& \mathrm{K}=\text { kejadian penyakit kuning (\%) } \\
& \mathrm{n}=\text { jumlah tanaman cabai yang terserang } \\
& \text { virus gemini } \\
& \mathrm{N}=\text { jumlah tanamaan tanaman cabai yang } \\
& \text { diamati }
\end{aligned}
$$

Perbanyakan Sumber Inokulum Virus. Tanaman tomat berumur 3-5 minggu yang akan digunakan untuk memperbanyak sumber inokulum ditanam pada polibeg (1-2 tanaman/polibeg) yang berisi tanah gembur dan steril (campuran tanah:pupuk kandang
2:1). Tanaman tomat dipergunakan sebagai tanaman inang atau tanaman perbanyakan virus karena relatif lebih mudah pemeliharaannya dan umurnya relatif lebih lama dibandingkan tanaman cabai serta tidak mengandung zat inhibitor untuk kegiatan teknikteknik molekuler. Untuk mendapat sumber inokulum virus gemini yang diharapkan murni maka diperlukan penularan menggunakan $B$. tabaci. Serangga vektor dewasa (15-20 ekor/tanaman) diberi makan tanaman sakit selama 24 jam untuk periode makan akusisi. Kemudian serangga dipindahkan ke tanaman sehat untuk periode makan inokulasi selama 24 jam. Setelah itu serangga dimusnahkan dan tanaman dipelihara di rumah kaca untuk diamati perkembangan gejala yang muncul.

Deteksi Virus dari Tanaman Sampel dengan Teknik PCR. Teknik PCR yang digunakan untuk mendeteksi virus gemini dari sampel tanaman meliputi tiga tahapan, yaitu ekstraksi DNA, amplifikasi DNA, dan visualisasi hasil PCR.

Ekstraksi DNA. Ekstraksi DNA dari sampel jaringan tanaman dilakukan dengan mengikuti prosedur Dellaporta (1983). Daun tanaman sakit (seberat 0,5-1 g) dimasukkan ke dalam tabung eppendorf kemudian ditambahkan $500 \mu \mathrm{l}$ bufer (100 mM Tris pH 8, $50 \mathrm{mM}$ EDTA, $500 \mathrm{mM} \mathrm{NaCl}$ ) dan $\beta$-mercaptoethanol (5\%). Setelah daun digerus ditambahkan $500 \mu$ phenol chloroform isoamylalcohol (PCI) (25:24:1) dan divorteks supaya tercampur baik. Kemudian disentrifugasi dengan kecepatan $12.000 \mathrm{rpm}$ selama 5 menit pada suhu $25^{\circ} \mathrm{C}$ dan diambil supernatannya. Pada supernatan yang diperoleh ditambahkan $33 \mu \mathrm{l}$ SDS 20\% dan kemudian divorteks. Setelah diinkubasi pada suhu $65^{\circ} \mathrm{C}$ selama 10 menit ditambahkan $160 \mu \mathrm{l} 5 \mathrm{M}$ KoAC, divorteks, disentrifugasi $12.000 \mathrm{rpm} 5$ menit suhu $25^{\circ} \mathrm{C}$, dan diambil supernatannya. Langkah terakhir ini diulang sekali lagi. Pada hasil supernatan yang kedua ditambahkan 0,5 volume isopropanol, divorteks, disentrifugasi $12.000 \mathrm{rpm} 5$ menit pada suhu $25^{\circ} \mathrm{C}$. Pada tahap ini suspensi dibuang, sedangkan pelet dicuci dengan menambahkan $500 \mu \mathrm{l} 70 \%$ etanol, disentrifugasi $12.000 \mathrm{rpm} 5$ menit pada suhu $25^{\circ} \mathrm{C}$, dan dibuang supernatannya. Pelet yang diperoleh diresuspensi dengan $300 \mu \mathrm{l} \mathrm{H}_{2} \mathrm{O}$. Selanjutnya dilakukan ekstraksi dengan menambahkan $300 \mu \mathrm{l}$ PCI, divorteks, disentrifugasi $12.000 \mathrm{rpm} 5$ menit suhu $25^{\circ} \mathrm{C}$. Lapisan atas dipindahkan ke tabung baru dan 
ditambahkan 0,1 volume NaOAC dan 1 volume etanol absolut, diinkubasi pada $-20^{\circ} \mathrm{C}$ selama 20 menit dan disentrifugasi. Pelet yang diperoleh dicuci dua kali dengan etanol $70 \%$ masing-masing sebanyak $500 \mu \mathrm{l}$. Pelet yang dihasilkan dikeringkan (kering udara dan vakum) kemudian diresuspensi dengan $30 \mu \mathrm{l} \mathrm{H}_{2} \mathrm{O}$ dan suspensi tersebut disimpan sebelum digunakan lebih lanjut.

Amplifikasi DNA. DNA hasil ekstraksi diamplifikasi dengan teknik PCR mengikuti prosedur Rojas et al. (1993), dengan primer universal virus gemini (PAL1v 1978 dan PAL1c 715) yang akan mengamplifikasi bagian gen protein replikasi dan protein selubung dengan ukuran fragmen DNA yang diharapkan $\approx 1,6$ kb. Reaksi PCR (total volume $25 \mu \mathrm{l}$ ) menggunakan Ready To Go PCR Beads (Amersham Pharmacia Biotech) terdiri atas $10 \mu \mathrm{l}$ sampel DNA, 1 bead yang mengandung $200 \mu \mathrm{M}$ dNTP, 1.5 unit Taq DNA polimerase, $10 \mathrm{mM}$ Tris $\mathrm{HCl}, 50 \mathrm{mM} \mathrm{KCl}, 1.5 \mathrm{mM}$ $\mathrm{MgCl}_{2}$ dan primer PAL1v 1978 dan PAL1c 715 masing-masing sebanyak $1 \mu \mathrm{M}$. Ke dalam tabungtabung PCR diberi 1 tetes minyak mineral untuk mencegah penguapan. Tabung-tabung tersebut ditempatkan pada mesin PCR (thermal cycler) pada suhu $92^{\circ} \mathrm{C}$ selama 1-5 menit untuk pemanasan awal. Amplifikasi dengan PCR dilakukan sebanyak 35 kali dengan tahapan sebagai berikut: tahap I suhu $94^{\circ} \mathrm{C}$ selama 2 menit, tahap II suhu $55^{\circ} \mathrm{C}$ selama 2 menit, tahap suhu III $72{ }^{\circ} \mathrm{C}$ selama 3 menit. Akhir daur dipertahankan pada suhu $4{ }^{\circ} \mathrm{C}$ sampai tabung diambil. Hasil PCR disimpan di dalam freezer untuk digunakan lebih lanjut.

Visualisasi DNA. DNA virus gemini hasil amplifikasi dianalisis melalui elektroforesis menggunakan jel agarose 1\% (dalam TBE 0,5X) yang mengandung ethidium bromide. Untuk pengukuran DNA digunakan marker $1 \mathrm{~kb}$ ladder. Sampel disiapkan dengan mencampurkan $8 \mu \mathrm{l}$ DNA dan loading buffer sebanyak $2 \mu \mathrm{l}$. Selanjutnya masing-masing sampel diisikan dalam sumuran jel dengan pipet mikro. Elektroforesis dilakukan dengan tegangan $75 \mathrm{~V}$ DC selama 90 menit. Hasil eletroforesis tersebut dilihat dengan transilluminator UV dan dipotret.

\section{HASIL DAN PEMBAHASAN}

Pengamatan Penyakit Kuning di Lapangan. Pengamatan penyakit kuning di lapangan dilakukan pada beberapa lokasi yang berada di Propinsi
Lampung, Sumatera Selatan, Bengkulu, Jambi, Sumatera Barat. Tanaman cabai di lokasi pengamatan menunjukan variasi gejala yang cukup luas (Gambar 1) dan Tabel 1. Variasi gejala yang ditemukan pada cabai di lapangan dapat dikelompokkan sebagai berikut: (a) daun berwarna kuning total, (b) daun berwarna kuning, tetapi jaringan sekitar tetap hijau, (c) daun berwarna kuning dan daun membentuk lengkungan seperti kerupuk dan keriting, dan (d) tanaman kerdil dengan daun belang-belang kuning dan hijau.

Variasi gejala dipengaruhi oleh beberapa faktor seperti umur tanaman, kultivar, genotipe tanaman dan fase pertumbuhan tanaman. Faktor lain yang juga berpengaruh terhadap munculnya gejala adalah faktor lingkungan, seperti tingkat kesuburan tanah dan iklim di daerah pertanaman (Mattehews, 1992). Lebih lanjut Polston (1996) melaporkan bahwa ekspresi gejala pada tanaman yang terinfeksi virus gemini juga dipengaruhi oleh strain dan umur tanaman waktu terinfeksi. Sulandari (2004) melaporkan bahwa dari pengamatan lapangan di daerah Yogyakarta, Jawa Tengah, dan Jawa Barat tanaman cabai yang terinfeksi virus gemini memiliki variasi gejala seperti tulang daun berwarna hijau dengan jaringan kuning, daun kuning dengan tulang daun tebal, tulang daun kuning tetapi jaringan tetap hijau dan daun hijau dengan tepi daun melengkung ke atas. Sulandari (2004) juga melaporkan bawah penularan virus gemini pada berbagai kultivar cabai di rumah kaca memiliki variasi gejala seperti nekrotik kuning, vein clearing dan sistemik pada cabai rawit kultivar Cakra. Rusli (2000) melaporkan gejala pada tanaman cabai di lapangan di daerah Cipanas, Cugenang dan Baranasiang mencakup gejala daun menguning, daun mengecil, mosaik kuning dengan serangan mencapai $100 \%$.

Penyebaran dan Kejadian Penyakit Kuning Rerata kejadian penyakit kuning dan penyebarannya di lapangan, yaitu di Propinsi Lampung, Sumatera Selatan, Bengkulu, Jambi, Sumatera Barat dan Sumatera Utara dapat dilihat pada Tabel 1. Berdasarkan hasil pengamatan di berbagai lokasi diketahui bahwa gejala yang mirip dengan serangan virus gemini sudah tersebar luas di Sumatera, terutama di Lampung, Sumatera Selatan, Bengkulu, dan Sumatera Utara. Sedangkan di Propinsi Jambi dan Sumatera Selatan gejala kuning hampir tidak ditemukan, gejala yang ditemukan hanya keriting.

Tingkat kejadian penyakit di Propinsi Lampung dan Sumatera Utara bervariasi antara 30-80\%, 
Tabel 1. Tipe gejala, penyebaran dan kejadian penyakit kuning pada cabai di lapang

\begin{tabular}{|c|c|c|c|}
\hline $\begin{array}{c}\text { Lokasi Pengamatan } \\
\text { (Propinsi-Kabupaten) }\end{array}$ & Tipe Gejala & Penyebaran & Kejadian Penyakit \\
\hline $\begin{array}{l}\text { Lampung } \\
\text { - Lampung Barat } \\
\text { - Tanggamus }\end{array}$ & $\begin{array}{ll}\text { - } & \text { Kuning } \\
\text { - } & \text { Kerdil } \\
\text { - } & \text { Keriting }\end{array}$ & $\begin{array}{l}\text { - Sporadis } \\
\text { - Total }(V+G) \\
\text { - Total (G) }\end{array}$ & $\begin{array}{l}-0-30 \% \\
-80-100 \% \\
-50-100 \%\end{array}$ \\
\hline $\begin{array}{l}\text { Sumatera Selatan } \\
-\quad \text { Muara Dua }\end{array}$ & $\begin{array}{ll}\text { - Kuning } \\
\text { - Kerdil dan keriting }\end{array}$ & $\begin{array}{l}\text { - Sporadis } \\
\text { - Total }(\mathrm{V}+\mathrm{G})\end{array}$ & $\begin{array}{l}-0-20 \% \\
-40-60 \%\end{array}$ \\
\hline $\begin{array}{l}\text { Bengkulu } \\
\text { - Curup }\end{array}$ & $\begin{array}{ll}- & \\
\text { - } & \text { Kuning } \\
\text { - } & \text { Keriting } \\
\end{array}$ & $\begin{array}{l}\text { - Sporadis } \\
\text { - Sporadis } \\
\end{array}$ & $\begin{array}{l}-0-40 \% \\
-0-40 \% \\
\end{array}$ \\
\hline $\begin{array}{l}\text { Jambi } \\
\text { - Kerinci }\end{array}$ & - - Keriting & - Sporadis & $-0-5 \%$ \\
\hline $\begin{array}{l}\text { Sumatera Barat } \\
\text { - Solok }\end{array}$ & - - Keriting & - Sporadis & $-0-5 \%$ \\
\hline $\begin{array}{l}\text { Sumtera Utara } \\
\text { - Brastagi }\end{array}$ & $\begin{array}{ll}\text { - } & \\
\text { - Kuning } \\
\text { - Kerdil dan keriting }\end{array}$ & $\begin{array}{l}\text { - Sporadis } \\
\text { - } \quad \text { Total }(V+G)\end{array}$ & $\begin{array}{l}-0-30 \% \\
-20-80 \%\end{array}$ \\
\hline
\end{tabular}

Keterangan : V = Vegetatif, G= Generatif.

sedangkan di Sumatera Selatan berkisar 20-60\%, di Bengkulu berkisar 0-40\%, sedangkan di Jambi dan Sumatera Barat kejadian penyakitnya hanya kurang 5\%. Gejala keriting sehingga diperlukan uji molekuler untuk memastikan gejala tersebut disebabkan oleh virus gemini. Tingkat kejadian penyakit juga bervariasi antara cabai rawit dan cabai besar. Kejadian penyakit pada cabai rawit lebih tinggi di bandingkan pada cabai besar. Hal ini disebabkan oleh umur cabai rawit lebih lama (lebih dari 6 bulan) dan pengelolaan cabai rawit tidak seintesif cabai besar. Berdasarkan pengamatan di lapangan kultivar cabai besar yang ditanaman petani bervariasi tetapi secara umum adalah varietas-varietas hibrida, seperti TM 888, Hot Chilli, Panah Mas dan lain-lain. Sulandari (2004) melaporkan bahwa penyakit kuning yang ditemukan di daerah Yogyakarta, Jawa Tengan dan Jawa Barat memiliki tingkat serangan yang bervariasi dari ringan sampai berat dengan luas serangan 10-100\%. Cabai rawit di Yogyakarta pada telah terinfeksi virus gemini dengan serangan sangat berat dan kejadian penyakit $70-100 \%$ di daerah yang sama kejadian penyakit kuning pada cabai besar berkisar 10-30\% dengan tingkat serangan ringan dan berat.

Pola tanam seperti tumpang sari dan penggunaan mulsa plastik juga memberikan penaruh terhadap variasi terjadinya kejadian penyakit. Tanaman yang ditumpangsarikan dengan tanaman lain, seperti jagung, buncis, kacang panjang dan lainlain memiliki serangan lebih ringan dibandingkan tanaman cabai monokultur, sedangkan tanaman cabai yang tidak menggunakan mulsa plastik memiliki kejadian penyakit lebih tinggi dibandingkan tanaman yang menggunakan mulsa plastik.

Berdasarkan informasi dari petani di lokasi survey bahwa penyakit yang diduga oleh virus gemini telah ada sejak 2-3 tahun yang lalu, dan petani memberi nama penyakit bule karena penyakit tersebut mengakibatkan tanaman berwarna kuning total bila serangan berat (Gambar 1b dan 2a). Variasi gejala dan tingkat serangan juga berbeda beda di masing-masing lahan petani serta waktu tanaman. Bila serangan terjadi sejak tanaman masih muda (vegetatif) maka selain gejala kuning tanaman juga tumbuh kerdil dan tidak dapat tumbuh lebih lanjut seperti menghasilkan bunga atau buah, sedangkan bila serangan terjadi masa pertumbuhan generatif akhir maka hanya bagian atas saja yang menunjukkan gejala kuning (jambul kuning). Tanaman masih bisa berbunga dan buah pada bagian tanaman yang tidak terinfeksi virus (Gambar 2b). Waktu tanaman yang berbeda juga memberikan kejadian penyakit yang berbeda. Hal ini diduga terkait dengan dinamika populasi kutukebul. Ada beberapa pertanaman yang memiliki gejala sporadis atau hanya beberapa tanaman yang terserang dalam satu lahan petani, tetapi ada juga yang terserang total dengan gejala kuning. Hal ini terjadi baik pada fase vegetaif maupun generatif.

Epidemi penyakit tanaman dipengaruhi oleh 

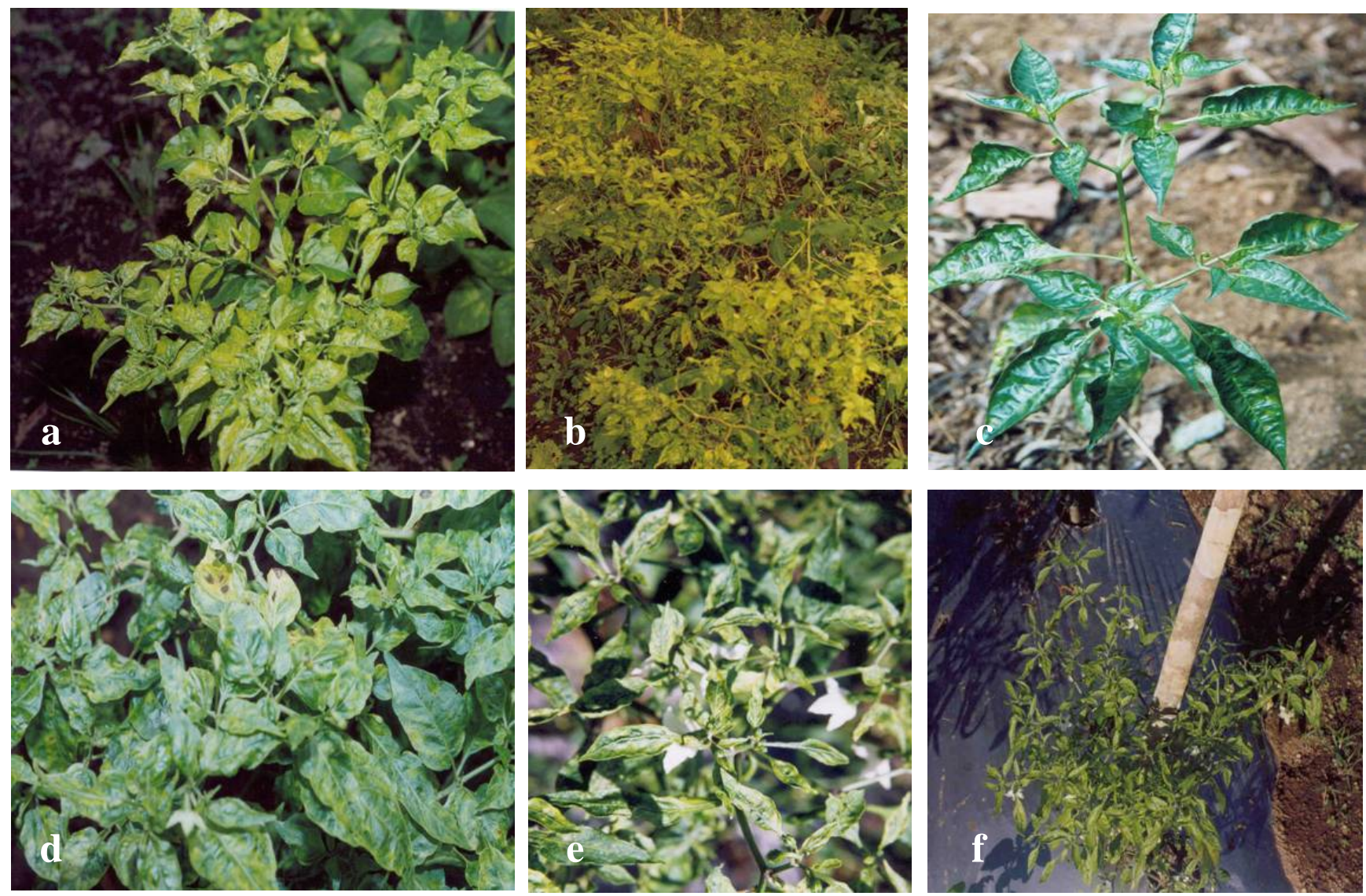

Gambar 1. Variasi gejala pada tanaman cabai yang terinfeksi geminivirus, a: daun kuning tetapi masih ada bagain hijau, b: kuning total, c: daun tebal dan berbentuk kerupuk d: daun hijau kekuningan, e: daun kuning dan menggulung, f: kuning dan tanaman kerdil
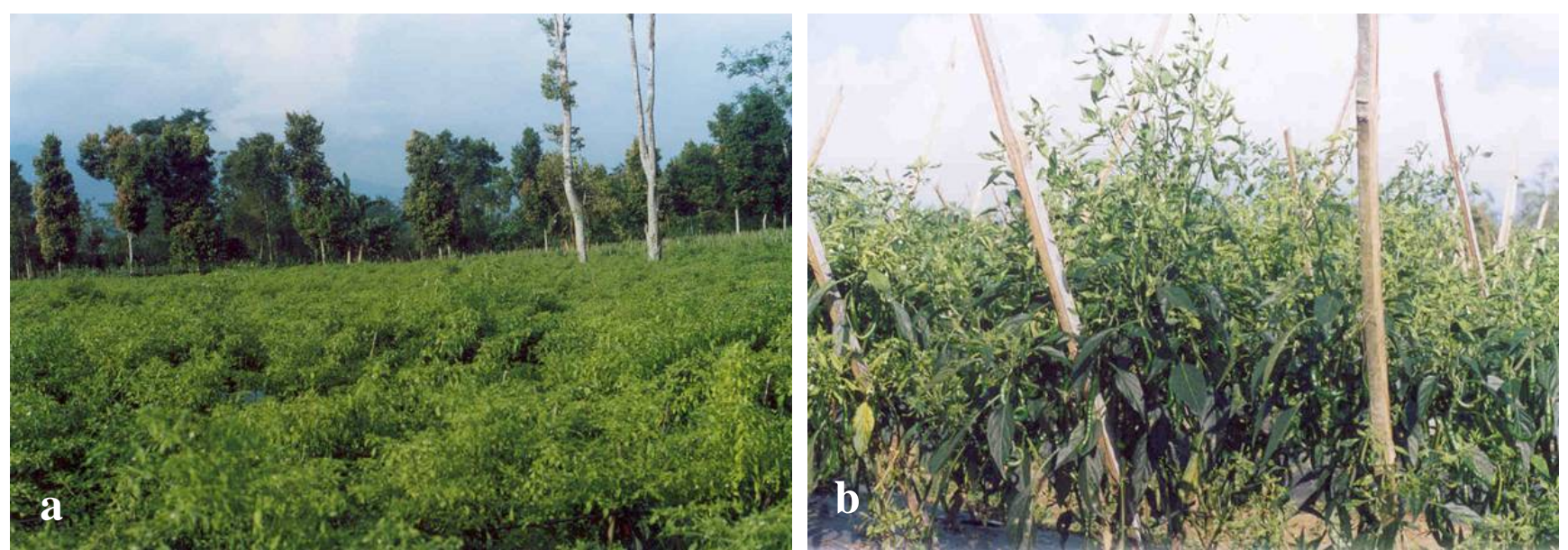

Gambar 2. (a) Populasi tanaman cabai yang terinfeksi geminivirus dengan tingkat serangan sangat berat, (lokasi Lampung Barat) (b) tanaman cabai yang terinfeksi pada fase generatif (tampak jambul kuning) (Lokasi Bengkulu) 
komponen inang, patogen, lingkungan, dan keterlibatan manusia, serta waktu yang akan mempengaruhi perkembangan penyakit (Agrios 2000). Selain kelima faktor tersebut epedimi penyakit yang disebabkan virus juga ditentukan oleh vektor, yang merupakan agens penyebar virus, sehingga epidemi juga sangat dipengaruhi dinamika populasi vektor. Epidemi penyakit kuning selain dipengaruhi oleh ledakan populasi kutukebul juga adanya kultivarkultivar cabai baru terutama hibrida yang lebih peka terhadap virus gemini. Perubahan pola tanaman dan anomali musim juga tampaknya berpengaruh secara langsung maupun tidak langsung. Faktor lain yang diduga juga ikut andil adalah adanya strain-strain dari virus gemini yang berbeda dari satu wilayah ke wilayah lainnya.

\section{Deteksi Virus dari Sampel Tanaman dengan} Teknik PCR. Ekstraksi DNA total menggunakan tanaman tomat yang berumur 10 hari, dengan pertimbangan bila langsung dari tanaman cabai keberhasilan sangat kecil mengingat tanaman cabai memiliki zat-zat inhibitor yang akan berpengaruh pada saat ekstraksi. Gejala masing-masing isolat pada tanaman tomat hampir sama yaitu daun menggulung menyerupai mangkuk, warna kuning sebagian, tulang daun menebal, daun mengecil, tanaman mengalami malformasi dan kerdil serta tidak menghasilkan bunga dan buah atau bila menghasilkan buah maka mulai berbunga lebih lama dibandingkan tanaman sehat (Gambar 3).

Infeksi virus gemini berhasil terdeteksi dari tanaman asal Lampung, Sumatera Selatan, dan Sumatera Utara, sedangkan tanaman dari Jambi dan Sumatera Barat meberikan reaksi negatif. Deteksi DNA ini berkorelasi dengan hasil pengamatan gejala, kecuali sampel dari Bengkulu. Walaupun secara gejala tampak ternyata hasil PCR bereaksi negatif (Gambar 4). Hal ini diduga karena adanya hambatan dalam ekstraksi di laboratorium atau faktor-faktor lain yang belum diketahui. Pita DNA berukuran 1.5 kb tampak pada gel agarose (1\%) proses amplifikasi dengan teknik PCR menggunakan primer universal virus gemini PAL1v 1978 dan PAL1c 715. Fragmen DNA dengan ukuran tersebut sesuai dengan ukuran yang diharapkan dengan primer tersebut (Rojas et al., 1993). Sulandari (2004) melaporkan bahwa teknik PCR dengan primer pUPv1 \& pUPc2 yang digunakan untuk mengamplifikasi genom virus gemini secara utuh dengan ukuran 2,6 kb dan primer pAv 494 \& pAc 1048 yang mengamplifikasi pada bagian genom protein selubung pada ukuran $550 \mathrm{bp}$.

Teknik PCR juga dapat digunakan untuk mendeteksi virus gemini pada vektor seperti yang dilaporkan oleh Nooraidawati (2000) yang melakukan deteksi virus gemini pada B. tabaci. Keberhasilan teknik PCR mendeteksi virus gemini pada tanaman dan serangga vektor menunjukkan teknik tersebut dapat digunakan sebagai bagian dari strategi pengendalian penyakit terutama untuk digunakan dalam penentuan peringatan dini di lapangan. Primer PAL1v 1978 dan PAL1c 715 merupkan primer universal virus gemini yang dirancang berdasarkan sekuen DNA beberapa virus gemini (Rojas et al. 1993). Dengan pasangan primer yang sama Rusli (2000) berhasil mendeteksi virus gemini dari tanaman cabai. Wang et al. (1996) melakukan pengujian virus gemini dengan primer PAL1v1978 dan PAR 1c496 dan memperoleh fragmen DNA pada ukuran 1,1 kb. Chiang et al. (1997) dengan primer PAC1v1978 dan PAV1c 715 mendeteksi virus gemini pada kutukebul yang diakuisisikan pada tanaman tomat sakit dan berhasil memperoleh fragmen DNA ukuran 1,5 kb. Kato et al. (1998) mendeteksi virus TYLCV dengan teknik PCR dengan menggunakan primer A-1 dengan hasil fragmen pada berukuran 1,3 kb.

\section{SIMPULAN}

Hasil percobaan dapat kami simpulkan bahwa pertanaman cabai di Pulau Sumatera telah terinfeksi virus gemini berdasarkan pengamatan gejala dan molekuler. Virus gemini terjadi di Propinsi Lampung, Sumatera Selatan dan Sumatera Utara, sedangkan di Propinsi Bengkulu gejala virus gemini ditemukan tetapi virus gemini tidak terdeteksi. Tanaman cabai di Propinsi Jambi dan Sumtera Barat tampaknya belum terinfeksi virus gemini. Tipe gejala yang ditemukan yaitu kuning, keriting, dan kerdil dengan kejadian penyakit bervariasi untuk Propinsi Lampung berkisar 0-100\%, Sumatera Selatan 20-60\%, Bengkulu 0-40\%, Jambi 0-5\%, Sumatera Barat 0-5\% dan Sumatera Utara $0-80 \%$.

\section{SANWACANA}

Artikel ini merupakan bagian hasil penelitian yang didanai oleh Hibah Pekerti tahun 2004-2005. Penulis mengucapakan terima kasih. kepada DP3MDIKTI dan Ir. Nooraidawati, M.Si (Mahasiswa S3) atas dukungan dan bantuan teknis selama melakukan uji PCR di Laboratorium Virologi IPB. 

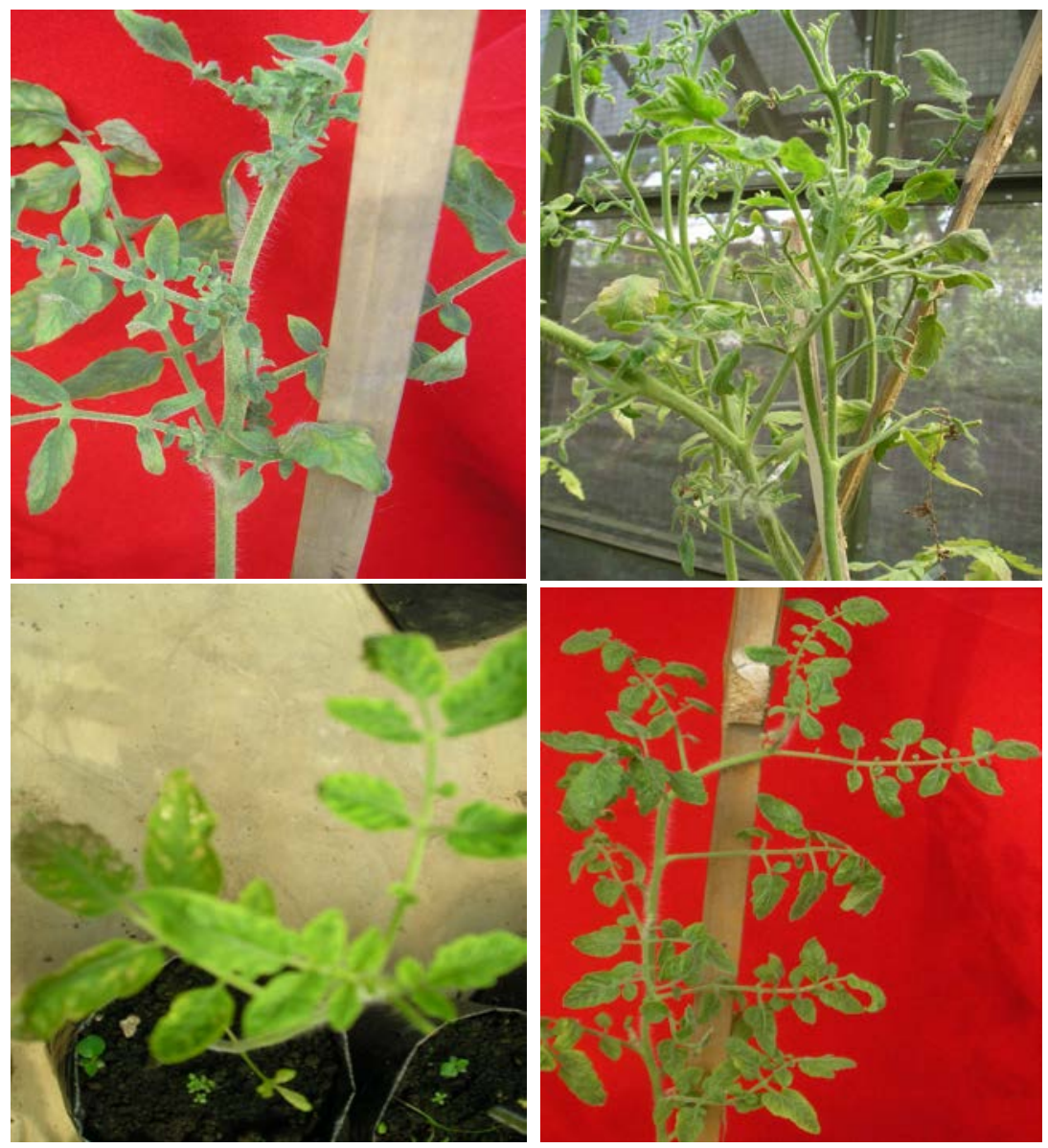

Gambar 3. Variasi gejala infeksi virus gemini pada tanaman tomat sebagai tanaman model untuk analisis molekuler

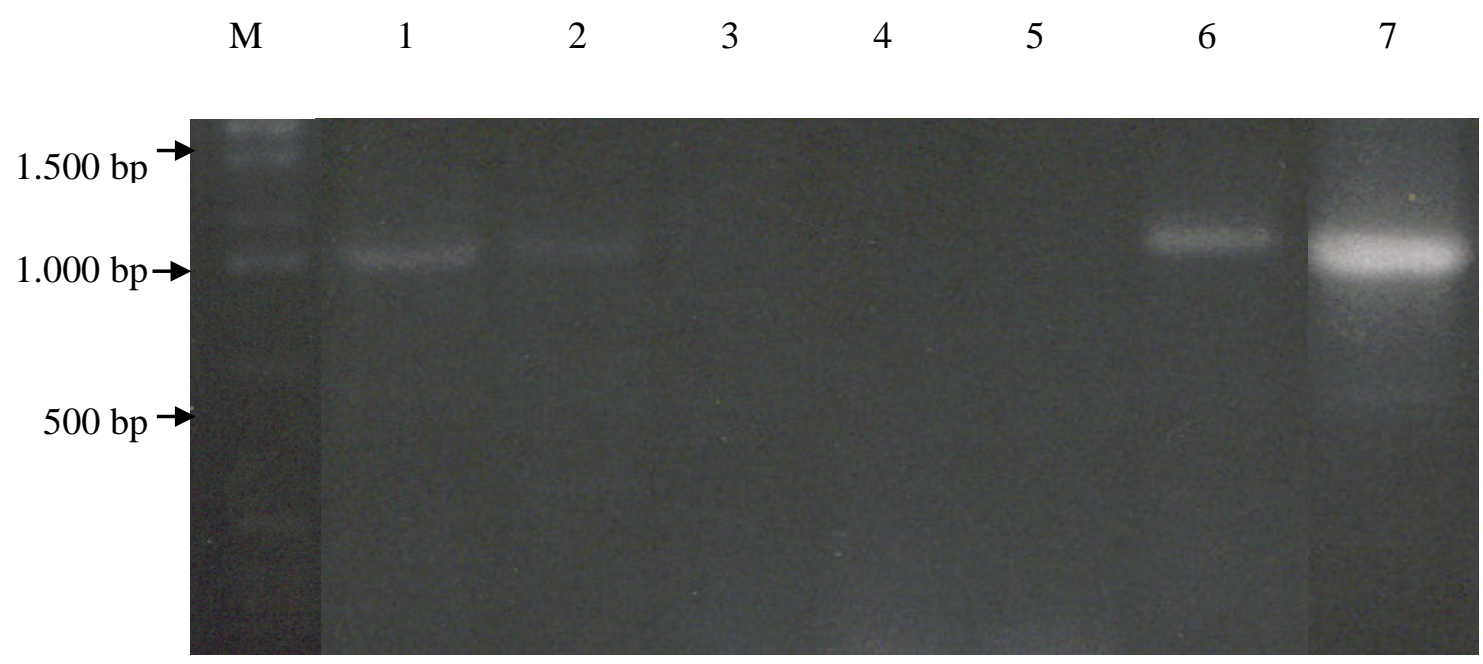

Gambar 4. Fragmen DNA hasil amplifikasi menggunakan primer pAL1v1978 \& PAR 1C496. M: marker 100 bp, (1) isolat Lampung (+), (2) Isolat Sumatera Selatan (+), (3) Isolat Bengkulu (-), (4) Jambi ( -), (5) Sumatera Barat (-), (6) Sumatera Utara (+), dan (7) Kontrol positif 


\section{DAFTAR PUSTAKA}

Agrios, G.N. 2000. Ilmu Penyakit Tumbuhan. Terjemahan Busani. Gajah Mada University Press. Yogyakarta.

Bock, K.R. 1982. Geminivirus diseases. Plant Disease 66 (3): 266-270.

Chiang, B.T., M.K. Nakhla, D.P. Maxwel, W. Schoenfelder \& S.K. Green. 1997. A new geminiviruses association with a leaf curl disease of tomato in Tanzania. Plant Disease 81:1111 (abstract).

Harrison, B.D. 1985. Advances in geminiviruses research. Annu. Rev. Phytopathol. 23:55-82

Hidayat, S.H., E S. Rusli, \& Nooraidawati. 1999. Penggunaan Primer Universal dalam Polymerase Chain Reaction untuk mendeteksi geminivirus asal cabe. Kongres \& Seminar Nasional Perhimpunan Fitopatologi Indonesia $X V$, Purwokerto. 16-18 September 1999.

Kato K., M. Onuki, S. Fuji \& K.Hanada. 1998. The first occurrence of tomato yellow leaf curl virus in tomato (Lycopersicon esculentum Mill). Ann. Phytopathol.Soc. Jpn. 64:552-559.

Mathews, R.E.F. 1992. Fundamentasl of plant virology. Academic Press Inc. San Diego. 403 p.

Mehta, P., J.A. Wyman, M.K. Nakhla, \& D.P. Maxwel. 1994. Polymerase chain reaction detection of viruliferous Bemesia tabaci (Homoptera: Aleyrodidae) with two tomato of infecting geminiviruses. J. Econ Entomol. 87(5):1285-1291.

Nooraidawati. 2000. Penularan virus kerupuk tembakau dengan Bemisia tabaci Genn. (Hemiptera: Aleyrodidae). Tesis. Institut Pertanian Bogor. Bogor. 48 hlm
Nooraidawati, S.H. Hidayat, R. Suseno, S. \& Sosromarsono. 2002. Transmission of an Indonesian isolate of tobacco leaf curl virus (Geminivirus) by Bemisia tabaci Genn. (Hemiptera: Aleyrodidae). Plant Path. J. 18(5):231-236

Nooraidawati, Yusriadi, \& S. H. Hidayat. 2001. Kisaran inang geminivirus asal tanaman cabai dari Guntung Payung, Kalimantan Selatan. Prosiding Kongres dan Seminar Nasional Perhimpunan Fitopaologi Indonesia XVI, Bogor-Jawa Barat. p 347-350.

Pico, B., M.J.Diez, \& F. Nuez. 1996. Viral diseases causing the greatest economic losses to the tomato crop II. The tomato yellow leaf curl virus. A review. Science Horticulture 67:151196.

Polston, J.E. \& P.K. Anderson. 1997. The emergence of whitefly-transmitted geminiviruses in tomato in Western Hemisphere. Plant Disease 81(12):1358-1369.

Rojas, M.R., R.L. Gilbertson, D.R. Russel, \& D.P. Maxwel. 1993. Use of degenerate primers in the polymerase chain reaction to detect whitefly trasmitted geminiviruses. Plant Disease. 71:340-347.

Rusli, E.S. 2000. Deteksi dan karakterisasi geminivirus asal cabai rawit (Capsicum frustescens L). Tesis. Pascasarjana Institut Pertanian Bogor. Bogor. $42 \mathrm{Hlm}$

Rusli, E.S., S. H. Hidayat, R. Suseno, \& B. Tjahjono. 1999. Geminivirus asal Cabai : Kisaran Inang dan Cara Penularan. Bulletin HPT. 11(1): 126-131.

Sudiono, S. H. Hidayat, R. Suseno, \& S. Sosrpmarsono. 2001. Deteksi molekuler dan uji kisaran inang geminivirus asal tanaman tomat. Prosiding Kongres dan Seminar Nasional Perhimpunan Fitopaologi Indonesia XVI, Bogor, Agustus 2001.

Stenger, D.C., J.E. Duffus, \& B. Villalo. 1990. Biological and genomic properties of geminivirus isolated from pepper. Phytopathology 80:704-709. 
Sulandari,S., R. Suseno, S. H. Hidayat, J. Harjosudarmo, \& S. Sosromarsono. 2001. Deteksi geminivirus pada cabai di Daerah Istimewa Jogyakarta. Prosiding Kongres dan Seminar Nasional Perhimpunan Fitopaologi Indonesia XVI, Bogor, Agustus 2001.

Sulandari, S. 2004. Karakterisasi Biologi, Serologi, dan Analisis Sidik Jari DNA virus Penyebab Penyakit Keriting Cabai. Disertasi. Sekolah Pascasarjana IPB. Bogor. 175 hlm.
Trisusilowati, E.B. R. Suseno, S. Sosromarsono, Barizi, Soedarmadi \& M.A. Nur. 1990. Transmissions, serological asspects and morphology of the tobacco krupuk virus. Indon. J. Trop. Agric. Vol 1 (2). P 38-42.

Wang, H.L., R.L. Ilbertson \& W.J. Lucas. 1996. Spatial and temporal distribution of bean dwarft mozaic geminivirus in Phaseolus vulgaris and Nicotiana bentheamiana. Phytopathol. 86:1204-1213 